\title{
Fecundity of Mozambique Tilapia (Oreochromis Mossambicus Peters) from Reservoirs of Beed District in Maharashtra, India
}

\author{
Sakhare $\mathrm{VB}^{1 *}$ and Chalak $\mathrm{AD}^{2}$ \\ ${ }^{1}$ Department of Zoology, Yogeshwari Mahavidyalaya, India \\ ${ }^{2}$ Department of Zoology, Late Shankarrao Gutte Gramin Arts, Commerce and Science College, India
}

Submission: October 25, 2019; Published: November 27, 2019

Corresponding author: V B Sakhare, Post Graduate Department of Zoology, Yogeshwari Mahavidyalaya, Ambajogai, Maharashtra, India

\begin{abstract}
Observations made on the fecundity of the mozambique tilapia (Oreochromis mossambicus) from reservoirs of Beed district, Maharashtra, India are reported. The ovarian eggs were found to be of different sizes. The number of ova per gram mature ovary ranged from 235 to 390 and the number of ova per gram body weight, from 6.41 to 9.92, the average being 9.01. The fecundity increased with the increase in size of fish.

Keywords: Oreochromois mossambicus; Fecundity; Reservoirs; Maharashtra; India
\end{abstract}

\section{Introduction}

Tilapia is native to Africa and Middle East and has emerged from mere obscurity to one of the most productive and internationally traded food fish in the world [1]. The last three decades have seen significant developments in farming of tilapias worldwide. They are being farmed in about 85 countries worldwide Tilapia belongs to the family Cichlidae under order Perciformes. There are about 70 species of tilapias, of which nine species are used in global aquaculture [2]. In India, tilapia (Oreochromis mossambicus) was introduced in 1952, with a view to filling up unoccupied niches such as reservoirs and ponds. These species spread across the country within a few years due to prolific breeding and adaptability to wide range of environmental condition. Introduction of tilapia in our culture system is advantageous because it represents lower level in food chain, and thus its culture will be economical and eco-friendly.

The term fecundity is generally used to denote the number of mature ova spawned by a female during its breeding season indicating the reproductive capacity of the fish [3]. The knowledge of the fecundity of a fish is extremely important for successful management and exploitation of its fishery. Therefore, fecundity of a species has direct bearing on the density of population of the species, survival and recruitment of new generation. Generally, species with a higher capacity for reproduction are subjected to lower rate of survival at various stages of development and vice versa. The fecundity of different Indian freshwater fishes has been reported in recent years. Notable among them were Sugunan and Vinci, Singh and Srivastava, Nauitiyal, Sakhare, Somdutt and Kumar, Alam and Pathak, Bhat, Mishra and Saksena, Chavan and Muley, Haque and Biswas, Priyadharshini et al. [4-16]. However, there has been no report on the fecundity of tilapia from Maharashtra State (India). Therefore, an attempt has been made to study the fecundity of tilapia (Oreochromis mossambicus) from reservoirs of Beed district (Maharashtra, India) for period of nine months i.e., February 2019 to October 2019.

\section{Materials and Methods}

The fish for present study were collected at random from different water bodies around Ambajogai in Beed district in Maharashtra (India) during the period from February 2019 to October 2019. A total of 15 specimens of Oreochromis mossambicus were collected in different months. The total length and weight of the fish were recorded to the nearest millimeters and grams respectively. In the present study, the gravimetric method was used for the estimation of fecundity. After liberation from the ovarian tissue, the ova were thoroughly washed and spreader on blotting paper to dry in air. The total number of ova so collected were weighed and the random samples of about 40 were counted and weighed. The total number of ova in the ovaries was then obtained from following formula [11]: 


$$
F=\frac{n G}{g}
$$

Where,

\section{$\mathrm{F}=$ Fecundity}

\section{$\mathrm{G}=$ Total weight of ova}

$\mathrm{g}=$ Total weight of subsample in sample unit

$\mathrm{n}=$ Number of ova in the subsamples.

\section{Results and Discussion}

Fecundity in O.mossambicus is very variable as reported by different investigators. According to Hora and Pillay [17], the female tilapia lays 75-250 eggs at a time. Vaas and Hoftstede [18] found that the fecundity of T.mossambica ranged from 80 to 300 ova for fish with length that ranges from 8 to $11 \mathrm{cms}$ in total length. Dietmar [19] counted eggs from ovaries of T. mossmabica and found them to range between 390 and 910 with female body weight ranging from 92 to 365 gms. Sukumaran [20] reported the range of fecundity in T.mossambica from 100 to 900 eggs in fishes ranging from 81 to $220 \mathrm{~cm}$ in total length. Kulkarni [21] reported the total number of ova in individuals varied from 169 to 772 in species ranging from 103 to $179 \mathrm{cms}$ in length. Mironova [22] reported that the fecundity of tilapia ranged from 80 to 1000 eggs per female. De Silva and Chandrasoma [23] found fecundity of 0 . mossambicus ranging from 360 to 1775 eggs per female for ranging from 20 to $31.9 \mathrm{~cm}$ in total length.

Ovarian wall becomes thin and highly vascular during the spawning period. Ovarian lumen is loosely organized, and zonation is not apparent. During the present investigation the fecundity of Oreochromis mossambicus varied from 188 (for a fish with total length $122 \mathrm{~mm}$ and body weight $29.3 \mathrm{gm}$ ) to 920 (for a fish with total length $194 \mathrm{~mm}$ and body weight $94.3 \mathrm{gm}$ ). The largest fish with a total length of $194 \mathrm{~mm}$ and body weight 94.3 gm showed the fecundity of 920 .The smallest sized fish in the sample with a total length $122 \mathrm{~mm}$ and body weight $29.3 \mathrm{gm}$ showed the fecundity of 188.The mean fecundity of 15 females was recorded as 618 eggs for a fish with a mean total length of $166.13 \mathrm{~mm}$ and mean body weight of $67.45 \mathrm{gm}$ (Table 1). The observed mean total weight of the ovary was $1.76 \mathrm{gm}$.

Table 1: Details of female specimens collected from reservoirs of Beed district in Maharashtra

\begin{tabular}{|c|c|c|c|c|c|c|}
\hline $\begin{array}{c}\text { Total length } \\
\text { (mm) }\end{array}$ & $\begin{array}{c}\text { Body weight } \\
\text { (gms) }\end{array}$ & $\begin{array}{c}\text { Ovary weight } \\
\text { (gms) }\end{array}$ & $\begin{array}{c}\text { Total number of } \\
\text { ova }\end{array}$ & $\begin{array}{c}\text { Number of ova/ } \\
\text { gm body weight }\end{array}$ & $\begin{array}{c}\text { Number of ova/ } \\
\text { gm ovary weight }\end{array}$ & $\begin{array}{c}\text { Ovary weight as } \\
\text { \% of body weight }\end{array}$ \\
\hline 122 & 29.3 & 0.798 & 188 & 6.416 & 235.58 & 2.723 \\
\hline 127 & 30.8 & 0.82 & 200 & 6.493 & 243.902 & 2.662 \\
\hline 139 & 47.7 & 1.375 & 398 & 8.34 & 289.454 & 2.882 \\
\hline 149 & 53.2 & 1.484 & 490 & 9.21 & 330.188 & 2.789 \\
\hline 157 & 56 & 1.58 & 515 & 9.196 & 325.949 & 2.821 \\
\hline 162 & 59.8 & 1.62 & 575 & 9.651 & 354.938 & 2.709 \\
\hline 165 & 62.3 & 1.79 & 610 & 9.791 & 340.782 & 2.873 \\
\hline 172 & 68.5 & 1.84 & 670 & 9.781 & 364.13 & 2.686 \\
\hline 178 & 72.3 & 1.975 & 695 & 9.612 & 351.89 & 2.731 \\
\hline 180 & 79.6 & 2.02 & 710 & 8.768 & 345.544 & 2.537 \\
\hline 182 & 87.6 & 2.08 & 780 & 8.904 & 375 & 2.374 \\
\hline 185 & 88.2 & 2.16 & 810 & 9.183 & 384.615 & 2.448 \\
\hline 188 & 90 & 2.22 & 825 & 9.166 & 371.621 & 2.466 \\
\hline 192 & 92.2 & 2.29 & 895 & 9.92 & 390.829 & 2.483 \\
\hline 194 & 94.3 & 2.37 & 920 & 9.75 & 388.185 & 2.513 \\
\hline
\end{tabular}

During present investigation the numbers of eggs were directly proportional to the weight of the fish and the fecundity increased progressively with ovary weight of fishes. Similar observations were also made by Roy et al. [24] and Parameswaran et al. [25]. Hatikakoty and Biswas [26] observed fecundity of O.mossambicus in the range of 546 to 1550 eggs/100 g body weight. In the present investigation it was observed that fecundity of 0 . mossambicus ranged from 641.6 to 992 eggs/100 g body weight indicating that the fecundity recorded in the present investigation was like those recorded elsewhere. The low fecundity in O.mossambicus could well be attributed to the parental care. Furthermore, the low fecundity of O.mossambicus also might be due to prolonged breeding season. The ovary weight as percentage of the total weight of fish ranged from 2.37 to 2.88 with an average of 2.6.

\section{References}

1. National fisheries Development Board (2015) Guidelines for Responsible farming of Tilapia in India, Department of Animal Husbandry, Dairying and Fisheries, Government of India, New Delhi.

2. Food and Agriculture Organization of the Unites Nations (2008) The state of world fisheries and aquaculture, FAO Fisheries and Aquaculture Department, FAO of the United Nations, Rome, Pp. 196. 
3. Pillay TVR (1954) The biology of the gray mullet Mugil tade Forskal, with notes on its fishery in Bengal. Proc natn Inst Sci 20: 187-217.

4. Sugunan VV and Vinci GK (1981a) Length-weight relationship and food study of Rhinomugil corsula (Hamilton) with a note on its spawning and fecundity from Nagarjuna sagar reservoir, AP, India. Journal of The Inland Fisheries Society of India 13(1): 26-35.

5. Sugunan VV and Vinci GK (1981b) Biology of Labeo calbasu (Hamilton) of Nagarjunasagar reservoir, AP, India. Journal of The Inland Fisheries Society of India 13(2): 22-39.

6. Singh V and Srivastava P (1982) Fecundity study of three Indian major carps, Catla catla, Cirrhina mrigala and Labeo rohita, Indian Journal of Zoology 110 (1): 30-36.

7. Nauitiyal P (1985) Fecundity of Garhwal Himalayan mahseer Tor putitora (Ham.).Journal of Bombay Natural History Society 82(2):253257

8. Sakhare VB (2000) Fecundity of Catla catla (Hamilton) from Yeldari reservoir, Maharashtra. Journal of Aquatic Biology 15(1\&2): 50-51.

9. Sakhare VB (2012) In: Inland Fisheries, Daya Publishing House, New Delhi, India

10. Somdutt P and Kumar S (2004) Studies on fecundity of Puntius sarana (Ham.) in relation to total length, total weight and ovary weight. Journal of Indian Fisheries Association 31: 81-85.

11. Alam M and Pathak JK (2010) Assessment of fecundity and gonadosomatic index of commercially important fish, Labeo rohita from Ramganga river. International Journal of Pharma and Biosciences 1(3): 1-6.

12. Bhat AA (2012) Determination of fecundity of Schizothorax esocinus from river Lidder Kashmir. Report and Opinion 4(5): 55-57.

13. Mishra S and Saksena DN (2012) Gonadosomatic index and fecundity of an Indian major carp Labeo calbasu in Gohad reservoir. The Bioscan $7(1): 43-46$

14. D Chavan VR and Muley DV (2014) Study of gonadosomatic index and fecundity of fish Cirrhinus mrigala (Hamilton).The Bioscan 9(1): 167169.

15. Haque Shahlina and Biswas SP (2014) Some aspects of reproductive biology of Botia Dario (Hamilton-Buchanan) from Sivasagar district,
India. International Journal of Current Research and Academic Review 2(12): 71-77.

16. Priyadharshini R, Damodaran R and Kavitha P (2015) Gonadosomatic Index and fecundity of an Indian major carp Labeo rohita (Ham.). International Journal of Current Research 7(3): 14221-14224.

17. Hora SL and Pillay TVR (1962) Handbook of fish culture in the IndoPacific region. FAO Fish Biol Tech Pap 14: 204.

18. Vaas KF and Hofstede AE (1952) Studies on Tilapia mossambica Peters (Ikan mudjair) in Indonesia. In: Balai Penjelidikan Perikanan Darat, Bogor, Indonesia P. 68.

19. Dietmar R (1966) Some remarks on fecundity of Tilapia mossambica and its introduction in midcentral America, with first contribution to limnology of Nicaragua. Hydrobiologia 35(3/4): 357-388.

20. Sukumaran KK (1969) Growth, maturation and fecundity of cultivated fishes. FAO/UNDP Regional Seminar on induced breeding of fishes, Calcutta, India P. 53.

21. Kulkarni SS (1984) Biology of a cichlid fish Tilapia mossambica Peters from Marathwada region, Marathwada University, Aurangabad, India.

22. Mironova NV (1969) The biology of Tilapia mossambica Peters under natural and laboratory conditions. Vaprosy Ikhtiologii 9: 506-514.

23. De Silva SS and Chandrasoma J (1980) Reproductive biology of Sarotherodon mossambicus, an introduced species, in an ancient manmade lake in Sri Lanka. Environmental Biology of Fishes 5: 253-250.

24. Roy Animesh, Shakhawate Hossain, Mohammad Lutfar Rahman, Mohammad Abdus Salam and Mir Mohammad Ali (2014) Fecundity and gonadosomatic index of Glossogobius giuris (Hamilton,1822) from the Payra river, Patuakhali, Bangladesh. Journal of Fisheries 2(2): 141 147.

25. Parameswaran S, Alikunhi KH and Sukumaran KK (1972) Observation on the maturation, fecundity and breeding of the common carp, Cyprinus carpio Linnaeus. Indian Journal of Fisheries 19: 110-124.

26. Hatikakoty G and Biswas SP (2004) Studies on certain aspects of the reproductive biology of mouth-brooding tilapia, Oreochromis mossambicus (Peters) from Assam, India, Proceedings of the $6^{\text {th }}$ International Symposium on Tilapia in Aquaculture.

This work is licensed under Creative Commons Attribution 4.0 Licens DOI: 10.19080/OFOAJ.2019.11.555809
Your next submission with Juniper Publishers will reach you the below assets

- Quality Editorial service

- Swift Peer Review

- Reprints availability

- E-prints Service

- Manuscript Podcast for convenient understanding

- Global attainment for your research

- Manuscript accessibility in different formats ( Pdf, E-pub, Full Text, Audio)

- Unceasing customer service

Track the below URL for one-step submission https://juniperpublishers.com/online-submission.php 